\title{
ERASMUS EXPERIENCES IN THE UNIVERSITIES: THE JEAN MONNET MODULE AT PORTUCALENSE UNIVERSITY
}

\author{
Daniela Serra Castilhos \\ Portucalense University (PORTUGAL)
}

\begin{abstract}
In 2019 was celebrated the 30th anniversary of the Jean Monnet Activities through a series of events and other initiatives around the world. Over the last 30 years, a striking number of almost 5000 projects have contributed to the field of European integration studies. Currently half a million students benefit from the Jean Monnet Actions every year, which is now present in 87 countries worldwide. The present paper reports a case study on the Portucalense University (UPT) the "Jean Monnet European module: The European Union as a global player for Democracy and Fundamental Rights" aims to promote knowledge about the European Union from a legal perspective for a target audience made up of law graduates from Brazilian universities who are interested in pursuing graduate studies in Portugal The linguistic and cultural proximity between Portugal and Brazil makes it increasingly possible for Brazilian citizens to seek Portugal with the aim of taking postgraduate, masters and doctoral courses. This flow of people is in line with one of UPT's main strategic objectives: internationalization. In this regard, UPT has demonstrated, year after year, greater capacity to appeal to international students, with a significant number of Brazilian students. It was applied a questionnaire about the module. We conclude that the perception and interests of students was positive from the experience.
\end{abstract}

Keywords: Jean Monnet Activities, Erasmus Program, Portugal.

\section{INTRODUCTION}

The Jean Monnet programmes are currently coordinated within Erasmus+ activities, which has a significant role in higher education, since it encourages and supports the development of academic life, and the international circuit of educational, scientific, or cultural values.

The Erasmus+ programme represents a tool to tackle the internal challenges that the EU is facing at economic and societal level above mentioned, from the other side such programme is a key tool to foster the process of establishing a European Higher Education Area, started in 1998 with the Sorbonne Declaration and known as the Bologna process. [1] The programme for mobility of university students, Erasmus, was also upgraded to Erasmus+. [2]

The Jean Monnet activities are designed to promote excellence in teaching and research in the field of European Union studies worldwide. The discipline also covers the role of the EU in a globalized world and in promoting an active European citizenship and dialogue between people and cultures. The activities are supported teaching and research, support to associations, and policy debate with the academic world [3]

This initiative was named as a tribute to one of the founding fathers of the European Union. Jean Monnet was a french political and economic adviser, who reflected on the situation of Europe, the ages old antagonism between France and Germany and the need to solve the historical dispute between the countries. The perspective from Monnet was, as always, simple and pragmatic: to create strong ties, mutually beneficial, to connect the countries, in ways to allow the creation of bonds of true solidarity, strong and long-lasting between them.[4]

European Union as an organisation implements various instruments as well as initiatives to strengthen also to deepen the European integration process through various ways. One of the specific initiatives of European Commission is the Jean Monnet Project undertaken under the request of the universities, whose aim is to facilitate the introduction of European integration studies in universities. The Jean Monnet Action was launched in the member states of the European Union in 1990. The implementation of this initiative was forced of the strengthening of social activity and social affairs in EU and was closely connected with the third phase of European integration where social factor appeared as one of the main in the integration process. [5] 
Jean Monnet Activities supports projects aiming at enhancing study and research on the European integration process. The actions of the Jean Monnet activities can be of different typologies. For instance, they can be focused on teaching activities (Jean Monnet Modules and Jean Monnet Actions), in which teaching programmes on European studies should be delivered by one lecturer or by a group of lecturers in a higher education institution. [1]

The "Jean Monnet European module: The European Union as a global player for Democracy and Fundamental Rights" aims to promote knowledge about the European Union from a legal perspective for a target audience made up of law graduates from Brazilian universities who are interested in pursuing graduate studies in Portugal.

The module is designed in accordance with priority target groups of the Jean Monnet Action, namely "Institutions or academics not yet in receipt of Jean Monnet funding", since UPT has not yet received any Jean Monnet funding. In addition to that, graduates from Brazil form part of "Students who do not automatically come into contact with European Union studies".

The external dimension of the European Union educational policy in the Erasmus+ programme is represented by all those actions of the programme, which are oriented to foster the cooperation between European and third countries universities in the field of higher education. [1]

The linguistic and cultural ties between Portugal and Brazil makes it increasingly possible for Brazilian citizens to seek Portugal with the aim of taking postgraduate, masters and doctoral courses. This flow of people is in line with one of UPT's main strategic objectives: internationalization. In this regard, UPT has demonstrated, year after year, greater capacity to appeal to international students, with a significant number of Brazilian students.

The Module is structured in such a way as to combine a set of different objectives proposed as priorities in the Jean Monnet Action. The idea is to pass on knowledge to the Brazilian students eager to know more about the European Union, but also to disseminate this same knowledge to other scholars and to the civil society at large, so that, with the acquired knowledge. Brazilians will be able to find some solutions or ideas to solve their own problems, especially regarding Fundamental Rights.

In that sense, one of the objectives of the Module is to "promote research and first teaching experience for young researchers and scholars and practitioners in EU issues, "foster the publication and dissemination of the results of academic research", the "create interest in the EU and the constitution of the basis for future poles of European knowledge", deliver courses tailored to specific EU issues relevant for graduates in their professional lives.

In terms of impact, the Module will increase the knowledge of Brazilian students on European Union topics and will share this knowledge with civil society. The module's aim will be to help Brazilians find solutions to their own problems by using good practices from EU, especially on Fundamental Rights. Special attention will be given to the problems of federalism, asylum, immigration and corruption, which are of particular interest to Brazil, a huge federation of states with very different social and economic levels of development.

\section{METHODOLOGY}

This paper examines the effects of the first course held in the context of said Module for the development of students' concepts and goals related to EU issues.

The new course will also be created, called "European Union and its policies for Democracy and Fundamental Rights", with 32 contact hours, given in a concentrated way, whose faculty will be constituted by 6 university professors experienced in the subjects that will be covered in the course. The topics will deal with the European Constitutional Law, the Court of Justice of the European Union, European Maritime Policy, the internal effectiveness of Community law, the European Union as a global actor, Europe as a global actor in the defence of Human Rights and Democracy. The attendees who fulfil the attendance and assessment requirements will receive a certificate, with attribution of 8 ECTS.

The course took place on the days 3 to 6 of july of 2019 at the city of Porto in Portugal, it had 8 students, all brazilians. These students came from 7 different cities. Among those students, 7 where graduated in Law by brazilian universities, and 6 of them where studying for a Masters degree, at Universidade Portucalense. The last student was a graduate student at another portuguese university. A questionnaire was applied about the module, split in 2 parts: the first in regard to a teacher role at the teaching/learning 
process, and the value of the course in developing skills. The quiz had 10 questions, with 1 open question.

\section{RESULTS}

The regular curricula are often focused in repeatedly delivering the prepared materials to large groups of students, with the fixed structure; thereby courses in a form of a summer school provide the space for experimentation, collection of feedbacks, and thus development of the learning process. [6] We can observe it by this comment from one of the students: "The course was absolutely important to make sense of all the knowledge covered during the Masters course".

The programme has an impact on Erasmus students, who then possibly influence other students who are not directly involved in the programme. The impact on the individual choosing a study abroad is most intense through sponsoring of the Commission for Erasmus. The participation of individuals in different mobility programmes within the EU led to the increase of awareness and participation of other possible participants. [7] This advantage was expressed in the comment "The course surpassed all of my expectations, the classes were objective and very clarifying about the subject. I will recommend it to other people".

Several comments pointed out the content taught in the course would have a practical use in the professional lives of the students, as well as the continuation of development of their academic skills, for instance: "The content has shown the appearing of the European Union and its historical evolution which are the fundamental concepts for academic research I am working on", "the course is utmost importance for the academic education of brazilian students seeking for a global understanding of law. I congratulate this initiative and reinforce the request to keep it going."

The delivery of courses tailored to specific EU issues is very relevant for graduates in their professional lives. The comments from students have the same sense to them, for example: "The course was sensational, beyond any expectation. I see this course as a needed platform in order to begin studying law as an researcher of the European Union".

All of the students the maximum rate to the question about the importance of the course in developing their skills. It is shown in some comments: "I want to thank for the opportunity of a course so rich in knowledge, which in the end overcame all my expectations. It allowed me to understand how the works European Union in an efficient manner."

In some cases, they even compared it to courses of other areas: "the course provided me a significant vision of the fundamentals of the European Union, allowing me to understand better its systems and policies of growth and development. I emphasize that the course has proved itself more effective that my masters course to understand how the Union works."

The data were collected through a questionnaire applied to students in order to evaluate the didactic proposal. The results obtained, concerning to the students motivation in the contribution in the teaching process, were positive.

\section{CONCLUSIONS}

The development of the European Erasmus+ programme, which can be regarded as one of the "soft power" tools of the EU, contributes to internationalization of the portuguese higher education institutions. It provides not only opportunities to bridge cooperation between EU and non-EU countries and get additional funding for educational and scientific activities but more importantly - it creates incentives for modernization. It turns out to be extremely important for the Portucalense University, which have to face the challenge of strong competition in the global higher education system.

Furthermore, the students were greatly motivated thanks to the participative, active and collaborative environment resulting from the developed approach. These circumstances, with the good atmosphere in the classroom stands out, have favored the learning.

The learning process prepares students for the real world, they will shortly encounter mainly for interested in pursuing graduate studies in Portugal.

We conclude that the perception and interests of students were positive from the experience. 


\section{ACKNOWLEDGEMENTS}

The paper is prepared within the framework of Erasmus+ Jean Monnet Module " The European Union as a global player for Democracy and Fundamental Rights" (600502-EPP-1-2018-1-PT-EPPJMOMODULE, Erasmus+ Jean Monnet Actions) (2018-2021). The European Commission support for the production of this publication does not constitute an endorsement of the contents which reflects the views only of the authors, and the Commission cannot be held responsible for any use which may be made of the information contained therein.

\section{REFERENCES}

[1] A. Kinyakin e M. D. Martino, "Erasmus+ programme as factor of academic leadership for Russian HEls: a case of RUDN University," Advances in Social Science, Education and Humanities Research, vol. 318, pp. 262-271, 2019.

[2] P. Cacchione, "European Union Erasmus+ Program and the Jean Monnet Activities," Clinical Nursing Research, vol. 24, n 4, pp. 339-340, 2015.

[3] EACEA, "Jean Monnet," [Online]. Available: https://eacea.ec.europa.eu/erasmusplus/actions/jean-monnet_en. [Acedido em 14 Maio 2020].

[4] J. M. d. Campos, "Monnet, Jean," em Dicionário das Grandes Figuras Europeias, Lisboa, Assembleia da República, 2019, pp. 277-282.

[5] Ž. Paužaitè e K. Kriščiūnas, "Integration of Europe as the field of interest of Jean Monnet Project," European Integration Studies, vol. 2, pp. 38-45, 2008.

[6] I. Perko, "Evaluating learning activities relationships to social responsibility elements: a summer school case," em 13th International Scientific Conference SOCIAL RESPONSIBILITY AND CURRENT CHALLENGES 2018: SOCIAL RESPONSIBILITY AND SUSTAINABLE DEVELOPMENT IN SCIENCE, EDUCATION AND BUSINESS, Maribor, 2018.

[7] J. Kočová, EU citizenship and Mobility Programmes - Awareness of rights and possibilities within the EU, Wien: Universitat Wien, 2017. 